\title{
Tensions and Hopes for Embedding Peace and Sustainability in Science Education: Stories from Science Textbook Authors
}

\author{
Mijung Kim ${ }^{1,2}$ (D) David Wagner ${ }^{3} \cdot$ Qingna Jin $^{1}$
}

Accepted: 6 June 2021 / Published online: 28 July 2021

(C) Ontario Institute for Studies in Education (OISE) 2021

\begin{abstract}
In this paper, we explore how science textbook authors reconciled their personal hopes with disciplinary and societal demands in their writing. Using a qualitative narrative storytelling research method, we interviewed four Canadian science textbook authors about their hopes and the challenges they encountered in their writing. To understand their hopes, we distinguished between transcendent and immanent hopes, a distinction that was motivated by our initial interpretation of the interviews. All the authors described difficulties in addressing social issues in their science textbook writing in the processes of authorization and resistance from science teachers, which located their hope in the transcendent domain. Yet, their immanent hopes with the agency also emerged in the discussion of teachers' actions to develop and use alternative texts that engage with local socio-environmental issues, rather than on textbook content innovations. This suggests the need to support developing and experienced teachers as professionals in their decision-making about pedagogy and to equip them to critically examine available resources and write and share quality resources.
\end{abstract}

Résumé Dans cet article, nous tentons de déterminer comment les auteurs de manuels de science réussissent à concilier leurs attentes personnelles avec les exigences disciplinaires et sociétales de leur écriture. En utilisant une méthode de recherche qualitative fondée sur le récit narratif, nous avons eu des entretiens avec quatre auteurs canadiens de manuels de science pour parler de leurs attentes et des défis rencontrés dans leur processus d'écriture. Afin de comprendre leurs attentes, nous avons fait la distinction entre les attentes transcendantes et immanentes, une décision motivée par l'interprétation initiale faite des entretiens effectués. Tous les auteurs ont parlé de difficultés à traiter des enjeux sociaux dans leur écriture de manuels de science en ce qui concerne les processus d'approbation et ont mentionné

Mijung Kim

mijung.kim@ualberta.ca

1 Faculty of Education, University of Alberta, Edmonton, Canada

2 Faculty of Education, University of Alberta, 551 Education South, 11210-87 Avenue, Edmonton, AB T6G 2G5, Canada

3 Faculty of Education, University of New Brunswick, Fredericton, Canada 
une résistance affichée par les enseignants en sciences dont l'attente a été classée comme immanente. Pourtant, les attentes immanentes liées à leur capacité inhérente d'agir sont aussi ressorties de la discussion portant sur les actions prises par les enseignants pour développer et utiliser des textes alternatifs qui touchent aux enjeux socio-environnementaux locaux, plutôt qu'au nouveau contenu des manuels. Ceci fait entrevoir la nécessité d'offrir du soutien aux enseignants en formation et ceux d'expérience en les considérant comme des professionnels de la prise de décision dans le domaine de la pédagogie et en leur fournissant les outils requis pour évaluer les ressources disponibles de façon critique et pour rédiger et partager des ressources qui sont de qualité.

Keywords Science textbook authors $\cdot$ Scientific literacy for citizenship $\cdot$ Hope $\cdot$ Peace $\cdot$ Sustainability

\section{Introduction}

There are strong traditions of STEM education that focus on economic development and competencies for global competition. Sometimes these traditions could run parallel to educators' hopes for peace and sustainability. This paper presents intertwined narratives of science textbook authors and science educators working at reconciling personal, disciplinary, and societal demands. In the larger narrative, our experiences and background knowledge are interwoven as we ourselves have worked at making the aims of values including peace and sustainability and central to science teaching. This led us to look for conceptualizations of hope that would help us understand how these aims can appear in science education. We then explored the way science textbook authors reconciled their hopes for peace and sustainability with disciplinary demands in their authorship. Our attention to their narratives led us to fine tune our theorization of hope in relation to science education. Here we present the context of our initial work at embedding peace and sustainability into science education, followed by our theorization of hope that emerged in the end.

Our interest in hope had emerged from our participation in writing a guidebook with the Mahatma Gandhi Institute of Education for Peace and Sustainable Development (MGIEP), which is an arm of UNESCO, the United Nations Educational, Scientific and Cultural Organization (UNESCO MGIEP, 2017). The guidebook was to provide guidance to authors of textbooks who want to embed the United Nations' (2015) Sustainable Development Goals (SDGs) in the curriculum including peace and sustainability. In the writing process, there was much talk amongst the twenty-two educators and curriculum developers that centred on how to measure the effectiveness and efficiency of the guidebook. Measuring the effectiveness of its implementation could be seen as a deficit model and the goals are so far-reaching - a socially and environmentally sustainable world, thus, we asked what baseline could be used to develop the help of the guidebook and started to question the complexity of textbook authors' experiences in writing science textbooks. We further questioned how their hopes for peace and sustainability in science education were negotiated throughout textbook writing, taking hope as the baseline for changes in textbooks.

\section{Understanding Hope}

The word hope is used in a variety of ways. A general sense of hope might be described as either optimism or an attitude of resilience in the face of challenges. Alternatively, hope can refer to specific and distinct goals or wishes, which could be dependent on luck or on planning and effort (Snyder, 2002). In psychology literature (e.g. Idan \& Margalit, 2013), such hopes are usually in reference to the wishes of 
a particular person. In this sense, hope is seen as goal-oriented energy and pathway planning to bring desirable changes into one's life and society (Snyder et al., 2002). This goal-seeking may extend beyond the individual, because one's vision for the future necessarily involves wished-for relational situations (Ludema, 2000; Tiger, 1999). Psychology research often measures this kind of hope (Douglas \& Strobel, 2015) and identifies hope as a contributing factor in other endeavours (Adelabu, 2008; Chang \& Banks, 2007) or hope as a product of other factors (Hughes, 2011; Palaiologou \& Male, 2016).

Hopes motivate us to reflect on goals and take actions for desirable outcomes. To understand how hopes can be activated for goal-oriented action taking, we examine hopes in transcendent and immanent realms. Transcendence refers to something beyond reach and immanence to something within reach. People understand the goals and outcomes that need to be achieved; yet, they do not see they could take the goal-oriented actions. They are still optimistic and hopeful for the outcomes; yet, they place their hopes in something or someone outside of their locus of control, that is, transcendent hope. Immanent hope emerges when people place your hopes in something or someone within their circle of interaction. This hope can motivate them to take goal-oriented endeavours. The distinction between transcendence and immanence appears in scholarship in various contexts. The theorization of positioning makes a distinction between transcendent and immanent forces in interaction. Positioning theory (e.g. Harré \& van Langenhove, 1999) focuses on immanent interaction because it is "psychologically and socially real" in the shared community and discounts things transcendent as "intellectualizing myth" (Davies \& Harré, 1990, p. 43). In ecology, the term transcendence appears in a separate domain from human actions. Berry (2004), for example, described how we humans have been "caught up in our commitment to transcendence, to a transcendent personal creative deity, to a transcendent spiritual mode of the human-with a transcendent destiny" and connects this with the mind-body split often pinned on Descartes, leaving "the natural world soulless, since there was only mind and extension" (p. 149). Indigenous worldviews counter this transcendence-obsession by recognizing the intimate relationships among people and their environments (e.g. Wilson, 2001). Similarly, we see that new materialist ontologies developed by physicist Karen Barad and others promote a focus on immanence in recognition of the relational nature of experience and action, including human relationships with each other and with their physical material contexts (e.g. Barad, 2003, 2007).

From this understanding, we understand immanent hope as more active than transcendent hope because we position ourselves as one who can work towards our hopes, perhaps by influencing or leading the people around us to act in a certain way. With immanent hope, we could work towards personal responsibility and collective praxis. Personal responsibility is immediate responses to needs and problems. You see a problem and you attempt to fix it. Yet, problems in social contexts are often complex and going beyond a personal level because they are impacted by multiple actors. We alone cannot turn humanity's environmentally- and self-destructive tendencies around or even to make substantial impact for example, the climate crisis. In this way, hope needs to be aligned with collective praxis described by Freire (1994). For Freire (1994), the notion of praxis means to engage, enact, and embody our ideas, hopes, and responsibilities for change, which is possible through social and collective efforts. Halpin (2003) also highlights the collective agency that is necessary with hope, a collective leap. We put together Halpin's focus on the collective and Freire's focus on praxis to describe this kind of hope as collective praxis. We attempt to understand how hopes of the textbook authors are embedded in their narratives of textbook writing experiences.

\section{Studies on Science Textbooks and Textbook Authors}

There have been studies on science textbooks and textbook authors. Science textbooks are often taken as curriculum (Sunal \& Sunal, 2008; Zhao \& Hoge, 2005) and are the main instructional tool in classrooms 
(DiGiuseppe, 2014; Kelly, 2007). For instance, 75\%-90\% of instruction and 90\% of teacher-assigned homework are based on textbooks (Chambliss \& Calfee, 1998; Chiappetta et al., 2006). Thus, the quality of science textbooks has been crucial for educational effectiveness in teaching and learning in classrooms (Khine, 2013). Various approaches have been taken to understand the way science textbooks represent the discourse of science literacy. In content analysis, researchers have gauged the accuracy of content knowledge and misconceptions (e.g. King, 2013; Talanquer, 2007), linguistic resources of science content (e.g. Muspratt \& Freebody, 2013), and curriculum alignment (e.g., Davis \& Fonger, 2015). Most of these content analyses have focused on the communication and accuracy of science knowledge for the standardization of science curriculum, thus, researchers critiqued that textbooks contained narrow, empiricist views of science (Blachowicz, 2009; McTigue \& Slough, 2010) and lack of human agency and socio-scientific contexts (Calado et al., 2015; Salmani et al., 2015; Sharma \& Buxton, 2015). Kuhn (1970) described science textbooks as conservative exemplars of disciplinary paradigms, basing this claim on extensive experience with the genre rather than on rigorous analysis. Kuhn's recognition of the way textbooks present the least controversial aspects of a discipline reflects back on the tradition of textbooks even before 1970. However, this characteristic of textbooks in general continues to carry forward into the present (Hyland, 2000). Especially in science, school texts present selective representations of science understood and practised by scientists (Penney et al., 2003), and the texts are greatly shaped by social and political contexts (DeBoer, 1991; Rudolph, 2002, 2003). In this regard, how textbook authors are engaged in textbook writing could be questioned further.

Recent research shows that textbook authors' views of science and technology impact the content of textbooks (Malekan, 2008; Otto, 2018), including their views on how science and technology impact society (DiGiuseppe, 2014; Lee \& Catling, 2017). In Abd-El Khalick et al. study (2008), author effect was more evident than publisher effect. The study analysed how the nature of science (NOS) was presented in commercial science textbooks over four decades and found that the presentation and content of the NOS were changed when textbook authors were changed over time within a series of books from the same publishers. When the same authors wrote textbooks over four decades, there was no change in NOS inclusion, and sometimes there was less NOS (McDonald \& Abd-El-Khalick, 2017; Niaz \& Maza, 2011). As publishers' interests and decisions are likely to be oriented towards marketability rather than potential concerns with the content itself (DiGiuseppe, 2014), this research emphasizes that author effect was more influential on changes to the content and the approach of science in the textbooks. Yet, Altbach (1991) once stated that "textbooks are among the most political of commodities" (p. 243). What is included and how it is presented in textbooks are political concerns. Thus, textbook decisions in many parts of the world (Nishino, 2008) have resulted in "textbook wars" (Altbach, 1991, p. 243). This shows us that implementing new ideas or changes in commercial science textbooks is a complex process, which requires textbook authors significant reflection on social, cultural, and political paradigms in science and education. As DiGiuseppe's study (2014) showed, science textbook writing is a complex process of reflecting and working with different beliefs, worldview, interests, and paradigms in education. Thus, authors' own beliefs and hopes are continuously negotiated within the tension of the writing process.

\section{Research Process}

It is hard to imagine educators who do not claim to be working for a sustainable society and future; yet, from our experiences with science classrooms and textbooks, we see that sustainability and human values are not very prominent in school science broadly and science textbooks specifically. Why do textbooks avoid these important goals for human coexistence in our environment? This question motivates our interest in the tensions textbook authors experience in relation to their hopes for a sustainable future. 
In this study, we attempt to understand how textbook authors reconcile the competing demands of their disciplines, the relevant school discourses and their views on societal and environmental needs.

To understand the experiences and stories of textbook authoring, this study employed qualitative narrative storytelling in its research method. The complex nature of human experiences can be shared and understood in the form of storytelling (Clandinin \& Connelly, 2000). Narrative stories are one's voices, relationships, and reflections on experiences, which provide us social and cultural contexts of one's being and positioning in the community (Miller, 2009). The meaning of one's experiences becomes explicit in and through stories, which constitutes who one is (Goodson \& Gill, 2011). Narrative storytelling is a way of understanding human experiences in a collaborative manner of sharing and communicating between researcher and participants in social interactions. We, as inquirers, strive to enter in the matrix of personal and social contexts of textbook authors' stories to construct and reconstruct the meanings of "stories lived and told" in textbook writing (Clandinin \& Connelly, 2000, p. 20). From our participant authors' stories, we strove to understand how they were positioned in the action of textbook writing as educators, authors, and communicators, and how they experienced the cognitive dissonance among curriculum, prevailing education discourses, and personal hopes for sustainability and social connections of science.

Entering into the matrix of textbook authors' stories, the researchers' reflexivity is important in this study. In qualitative research, a researchers' theoretical knowledge, values, and experiences influence their observation, interpretation, and explanation, thus, it is critical that researchers are aware of and acknowledge reflexive procedures of the influential aspects which are otherwise hidden from others (Goldstein, 2016; Lichterman, 2017). Foregrounding reflexivity helps communicate to readers how interpretations and knowledge claims are situated based on the researchers' background knowledge and positions (Lichterman, 2017). Thus, we explicitly shared the backgrounds of our own hope and engagement in the discussion of embedding SDGs in science textbooks and guidebook development earlier. Our own experiences impacted our engagement with the participants' narratives throughout the study.

\section{Participants, Data Collection and Analysis}

We used convenience sampling to explore our research questions. As each province in Canada has a different curriculum, we contacted textbook authors in one province. We contacted some authors that we found from the identification of authors in the science textbooks used in the province, and we found some recommended by our colleagues. We contacted eleven authors, five of whom replied with positive responses. One author could not participate in the end due to busy schedules. Thus, only four authors participated to share their stories of textbook authoring (The names of the participants are pseudonyms). Four is a reasonable number of participants, that is common for narrative storytelling research. As our data will show, commonalities were evident in the participants' narratives, suggesting a degree of saturation. We did not have any other criteria on selecting authors except that they wrote science textbooks used in the province.

All four participant authors had been or were science teachers in Canadian high schools when they participated in textbook writing. John had written textbooks for around 35 years starting in the 1970s. He wrote chemistry and physics content for grades 10-12. Kurt was also a science teacher when he started to write textbooks together with John in the 1980s. Kurt and John were co-authors of several chemistry and physics textbooks. They wrote between ten and fifteen science textbooks together over three decades before they retired. After their retirement, they were active until recently in higher education and public education through lectures, seminars, and NGO activities. Lucas is a science teacher in a high school, mostly teaching chemistry and physics. He began textbook writing in the year 2000 for high school science in Grades 10-12. Mark was a science teacher, teaching mostly biology when he began textbook writing in 2005. He wrote biology sections in science textbooks for Grades 10-12. Later 
he was seconded to work in assessment with his province's Ministry of Education. When participating in this study, he was working at the Ministry.

In line with narrative storytelling research traditions, we convened two interview sessions for each participant. The interview questions were developed to help participants reflect and share their backgrounds, general interests, and experiences of science textbook authoring that could embrace their hopes and challenges in embedding peace and sustainability in science textbooks (see Appendix). We included the terms of peace and sustainability in our questions, and those terms were broadly expanded by the participants to talk about values and issues. They used the terms of issues, socio-scientific issues, social and environmental issues, values, peaceful or sustainable world to discuss peace and sustainability during their interviews. During the first storytelling session we provided each participant the same questions, and each session lasted about 60-80 min. In the tradition of narrative storytelling research, we followed the stories of the participants, encouraging them to tell us details, and allowing them to go on tangents. The second interview session for each author was a follow-up session to revisit and reflect on their stories from the first session, informed by our initial analyses. These follow-ups were done roughly 4 months after the initial interviews. We asked the authors if they would change any of their answers since the previous interview or add ideas. We also asked them to clarify and elaborate certain ideas that they had shared before. Approaching the end of our second interviews with the authors, we shared our guidebook (UNESCO MGIEP, 2017) with them and briefly explained the background and rationale of the guidebook. This was simply to share an example of other educators' efforts to embed values and issues in science textbooks. The authors shared their thoughts on this example by reflecting on and comparing their experiences. It is important to note that we only shared the guidebook with them after they shared their ideas so that that would not influence their answers.

All interviews were audio recorded and transcribed for analysis. The researchers reviewed the interview transcripts by colour-coding and came up with themes of textbook writing experiences to discuss transcendent and immanent hopes. The initial coding was done individually, and later there was a collective discussion to share our interpretation. This coding process was done twice over several months to examine possible themes of the participants' stories, centred around the challenges and opportunities they identified. During the first round of the coding process, we focused on what ideas were frequently and commonly emphasized among the participants' stories and coded their writing experiences in relation to curriculum, assessment, teachers, and students, social changes, and authorization process (the government and stakeholders as possible categorizations. In the second round, the initial categorizations were further negotiated and thematized into challenges (tensions between agency and authority, resistance and conflicts in classrooms) and possibilities (future alternative texts, and hopes in classroom actions). Based on thematization of the stories, we considered how the participants' stories located hope into immanent and transcendent realms. For immanent hopes we attended to whom the stories position with agency. For transcendent hopes we attended to what powers the authors depended on for their hopes within their stories. Throughout the data interpretation and discussion, our perspectives and theorization of hopes are interwoven, which is the practice of reflexive procedure in this study.

\section{Findings}

\section{Tensions Within Authorization Processes}

The agency as a textbook writer to make change is disappearing the more levels you go. (Lucas)

We expected that the textbook authors' agency and autonomy would have been challenged in various ways because textbooks have been recognized as a political commodity at least since the 1990s (e.g. Altbach, 1991). The textbook authors in this study described difficulties in writing due to the 
processes of authorization by various stakeholders. With awareness of the importance of connecting science to social issues in students' lifeworlds, the authors reflected on their experiences of bringing out related social issues of science in textbooks. Yet, during the authorization processes, the textbook contents were negotiated, revised or even deleted from the final version, which resulted in tension.

When John started writing science textbooks in the 1970s, he was working full time at a high school. He and his colleagues often discussed their frustrations with the current science textbooks, saying they were dry, abstract, and disconnected from students' interests and everyday worlds. With the emphasis of connecting science to students' lifeworlds, he and his colleagues, including Kurt, wrote a science textbook that included social and environmental issues in science. They both reported that the book was well accepted by teachers and students. At that time, this author group had selfpublished their books and thus held copyrights. John recalled they experienced much freedom and agency in textbook writing. They prioritized students' success in society through an STSC (Science, Technology, Society, and Communication) approach. However, later when John was writing similar content for government publications he encountered significant conflict. He remembered, "there was a lot of controversy around that too because it went a little further than they wanted me to go" (John, 1st interview). The tension was an ongoing issue for him during textbook writing and related authorization processes after that.

We had full autonomy in the 70s and 80s, we did not have full autonomy in the 90s... Because we had signed a contract with [ $\mathrm{N}$ publishers]... because [the government] declared that they were not ever going to authorize our work text again... I remember one particular incident of course with the STS stuff dealing with STS issues where she, she essentially said that, "No, you can't deal with those kinds of things in a textbook, I mean, people are going to become outraged that you're dealing with an issue, you know, that people have different opinions on." And I said, "yeah, we've been doing this for ten years now and we've never had one parent come to us and say that we're doing something wrong"...we had to fight our way through that in terms of getting societal issues included in our textbooks and we had a, a number of fights with the publisher. (John, 1st interview)

He closed his interview with a comment, "the textbooks will never be produced in the same way that they were produced [in the $70 \mathrm{~s}$ and $80 \mathrm{~s}$ ]". In his stories, we noted that many times, social and environmental issues were scrutinized, revised, and negotiated between the authors and the authorities of the government in the later review process. Kurt, who had been working with John also described this challenge.

The department of education had a very strict view of this, and you know for subjects like science, you know, they loved to list out all the facts that you had to teach. And they just couldn't and wouldn't look at expanding that beyond anything... There was a lot of resistance to that. (Kurt, 1 st interview)

This tension was echoed by the others. Lucas was a chemistry teacher when he was invited to write science textbooks. Lucas believed that science textbooks needed to tell the whole story of science in order to develop global citizenship with knowledge and skills. When he was writing a chemistry unit, he and his writing partner developed a two-page story of environmental chemistry based on the Bhopal disaster. Yet, he recalled the editing process as follows.

The agency as a textbook writer to make change is disappearing the more levels you go. So at the start, in your own writing, of course you can write whatever you want, but then, they're going to say, 'no, rewrite the section' ... I was writing about environmental chemistry and one of which is, we were asked to write towards the use of organic materials in the industry. And so it is petrochemical, and so I had written a thing about the Bhopal disaster, and how there are things we need to be aware of and the effects of some of these chemicals are sometimes not what we want them 
- or hope they would be. And that was very, very clearly not going to make it into the textbook.

(Lucas, 2nd interview)

He identified the importance of including balanced perspectives of the petrochemical industry including the dangers and safety issues; yet, it was discouraged. It was put in a corner of the textbook and watered down by the review panel of diverse stakeholders.

In the authors' stories, it was evident that there was resistance from the government sector, whose authorities were influenced by the local industry and economy. From the authors' stories, it was unclear to what extent the resistance was from active intervention from local industries or from the authorities' fear of complaints from the industries. Nevertheless, the authors experienced resistance. Mark explicitly recognized the power of the government in curriculum emphases. He explained, "if it's not evident and strong in the new curricula, then the resource can't really prop it up. ...I think the curriculum part is certainly very political". All the participants experienced and were aware of the tension of writing about social issues in science education. Writing science textbooks was indeed recognized as a political process. It is a complex process for writers to negotiate their own beliefs on science teaching and learning with the priorities of curriculum set by the government, and major industries in local communities. The tension between textbook writers' autonomy and stakeholders' authority was explicitly present in their stories.

\section{Challenges of Teachers' Views in Science}

I don't know how many times I was told, "this is not social studies. This is science, so why are we doing this?" (Kurt)

Textbook authors' decisions on what and how to write was also influenced by schoolteachers' perceptions and actions. Schoolteachers as textbook users and curriculum performers provide practical feedback and responses to textbook drafts. The textbook authors in our study were also teachers themselves and active in discussions amongst teachers when they were writing textbooks. Thus, they were aware of teachers' needs, perceptions, and potential resistance towards textbook contents. Additionally, once the authors had had publication experience, some of their previous textbooks had been already used by their peers at schools so there were opportunities to hear teachers' responses to their texts. For instance, Mark shared, "some teachers said 'I'll teach everything in the curriculum' and see if it's in the textbook". He also said he could observe how teachers used textbooks for assessment. Because they were aware that school teachers were concerned about the connection between science curriculum and textbooks, and that teachers even viewed textbooks as curriculum, it was a critical priority for the authors to address curriculum outcomes in the textbooks. Even though the curriculum and assessment focused more on the content knowledge of science, the authors also attempted to address the context of science with social justice, including ethical issues of genetics, safety, and sustainability. However, these efforts were not well received by some teachers who perceived this as not science. Some of the writers received feedback from teachers that those issues were not science, which led to their publishers' deleting or changing the sections of socio-scientific and environmental issues.

Another challenge, that I used to see this in the schools that I was at, is that some of the teachers weren't ready... They could deal with the technological applications...but not the society issues. I don't know how many times I was told, "This is not social studies. This is science, so why are we doing this?" (Kurt, 1 st interview)

Kurt who taught and wrote textbooks in the 1970s to 90 s described the resistance from teachers towards issue-based contents in science textbooks. Such resistance was similarly experienced by 
Lucas and Mark in the 2000s, who said the resistance persists in present science classrooms. Mark reflected on teachers' responses to linking science and social issues as follows.

They don't feel comfortable teaching it when it's not so factually based. Um, there is no right or wrong answer. It's something, it's almost this call to action which peace would also as a theme would also be... [they] just shy away from that because now that doesn't feel like science anymore because [they were] trained as a biology, chemistry or physics teacher...In most schools that I taught in and most teachers that I've talked to, they don't teach it at all... I think science teachers see themselves as, really many, as purveyors of facts rather than someone who's going to help students make societal decisions. (Mark, 1st interview)

Teachers' perceptions and reactions to social issues including peace and sustainability in science textbooks also influenced his writing. Mark reflected teachers viewed peace as a theme, not science, thus, inclusion of it was not part of their science teaching. His writing group attempted to take an interdisciplinary holistic approach to bring out everyday, social relations to science by telling stories. However, based on teachers' feedback, they were asked to rethink their approach and revise these sections.

Even when we were writing the textbooks for [Grade 8] Science and [Grade 9] Science, we set out with the idea that we would organize the information in this interdisciplinary way, that it would be like a narrative, or it would be like a story that would bring together many concepts. But as we wrote it, the feedback that we got from teachers was that that was not comfortable. They wanted units - they wanted discrete units of information chunked together, because that's the way that they wanted to teach... find that to be useful. So it required us to rethink and rewrite. (Mark, 2nd interview)

The perceptions of teachers towards issues and values in science textbooks were challenging for him. This challenge was also mentioned in Lucas's and John's stories: for example, "as teachers we could choose to teach that way or not. Some of us do and many of us don't... it's kind of an add-on at the end" (Lucas, 2nd interview).

Even though teachers were aware of the importance of issues such as climate change and ethical challenges of genetics, many of them would not teach these in class because they did not see them as science or because they are difficult to teach as the necessary approach would be very different from the way they were trained. In this story, it was evident that teachers' views on science teaching were more concerned with utilitarian approaches. John described the internal conflicts in science classrooms.

Lots of internal conflicts as well because you're trying to balance these pedagogical efficiency and exams and your students' future related to exams and your students' future related to they're citizens in a democracy. So you have all of these kind of factors which shouldn't be conflicting but because of the system and the structure of the system quite often they are conflicting. (John, 2nd interview)

He continued to describe that teachers could find time to follow their values, but "it's very difficult because you're working against the system" (John, 2nd interview). To help students be successful in the current system, he felt that some teachers chose to focus on contents for assessment. It was clear that the teachers' feedback internally and externally influenced decisions made by the textbook authors in this study. The tensions endemic in the multiple perspectives of science education are evident in the authors' stories about their interaction with teachers. Science teaching for utilitarian and vocational purposes orients students to succeed in the current educational system which is concerned with competencies and accountability in education through measuring students' knowledge and skills (Cannady et al., 2014; Loomis et al., 2008). 


\section{Possibility Sought in Alternative Texts}

I think that the textbooks of the future are likely to be more integrated with computers, internet, social media, search engines. (John)

As shown above, the textbook authors described for us how writing for social issues with/in science was not as effective as they expected and hoped for. Except for the case in which John, Kurt and their colleagues self-published their textbooks, the textbook content with issues was cut when it was deemed too controversial given the politics of curriculum and of the market-driven economy. There was also discomfort and resistance from teachers towards social issues in science textbooks. Further pedagogical conflicts expressed by teachers between addressing social values and teaching for students' academic success were expressed in the participants' stories.

Kurt and John, who wrote textbooks together and also taught science for about three decades, reflected that textbook writing for social justice and citizenship had not been much developed over time. Kurt reflected, "it seems to me that there is very little movement ... although I haven't done any research on that, but it's been very, very slow" because "the government and publishing companies have their own mindsets" (Kurt, 2nd interview). Their stories indicated it would be too challenging to address social and environmental issues in science textbooks under the current publishing systems. They sometimes used the words, 'not hopeful', 'helpless', and 'despair' to describe their concerns; yet, they soon turned these concerns to other ways to envision teaching resources to talk about hopes.

All the participant textbook authors mentioned possibilities for developing non-traditional formats of textbooks such as digital texts, from which teachers could pick and choose contents and contexts freely. When the resources are diverse with different perspectives and approaches, it would be more possible to develop integration of issues and values including peace and sustainability.

I think that the technology age is very exciting [...it's] shifting how you see yourself as an educator ...it's okay to say "I don't know but let's look it up. And let's talk about what's a good place to look it up". (Mark, 1st interview)

Social media is a huge game changer for education ... if a teacher in a classroom wants to make a politically-charged statement and the kids were to go on social media, that might spread rapidly through the social media... And of course, then that gets targeted back to the classroom. (Lucas, 2nd interview)

As much as they were aware of the possibility and accessibility of digital texts as teaching resources for issues and values in science, the authors also acknowledged the challenges of evaluating evidencebased information in this post-truth era. This has implications for teachers who find resources online because they have to use their critical skills to evaluate the material they find. It is also an imperative for good science teaching because students need to be guided to exercise such judgment. Knowledge of scientific processes and of accepted scientific findings can be a backbone of such critical judgment.

It's very difficult to determine what is actually going on to work through the news media and the influence of social media ... I think it is a double-edged sword...I could see some great advantages to social media and I understand the communication among young people has changed quite a bit but I mean there's also a great danger there illustrated by a number of things. So that's to me is a concern for children today. (Kurt, 1st interview)

Kurt acknowledged the possibilities and challenges in using web resources to teach science in social contexts. Developing students' awareness and skills of evidence-based evaluation on web resources is critical to bring this hope as possibility.

During the interviews, the authors' hopes for addressing significant social and environmental challenges were focused on alternative texts as it seemed hard for them to imagine any desirable changes in textbook writing in the coming future. We attribute this to their experiences as authors. As they foresaw 
textbooks becoming ever more commercialized and governed with the political agenda of curriculum development today, they mentioned using alternative texts such as web-based resources, which might be more effective and feasible for developing students' stewardship with science as citizens. When we consider the authors' hopes and fears in relation to their vision for science texts, we see the authors putting hope in free and open media (specifically the internet). They also positioned the presence of free and open media as a reason for science educators to be ever more vigilant about teaching science in connection with social issues. Thus, Internet phenomena are sources of fears and hopes.

\section{Hopes in Classroom Action}

The science teachers are the key. [...] In terms of promoting peace and sustainability [...] it's more than $[. .$.$] just the resource. (Mark)$

All of the participants were classroom teachers or former classroom teachers. Through their classroom experiences and their interactions as authors with teachers and groups of teachers, they described how textbooks were perceived and used by teachers and students. The authors understood the importance of teachers' views and beliefs in bringing socio-environmental concerns into science teaching. 'Good' science, according to the authors, requires cultural and democratic perspectives beyond utilitarian and economic aspects (Osborne, 2010). Their hope for developing responsible participatory scientific literacy was growing in and through teachers' action, not only in textbooks. Through teachers' interactions with textbooks and students, there is hope for local active engagement. Lucas reflected on the importance of teachers' action as the most important factor.

So again, it comes down to just the individual teacher. Are you willing to put that out there, and do you trust your science enough that, if somebody comes back at you and says, I don't like what you're doing, you can say, I'm doing it for this reason. You may not like what I'm doing, but you have to accept that this is something true. (Lucas, 2nd interview)

The authors were teachers when they first made decisions to bring stories and issues of science in society to classrooms and saw students' appreciation towards their approach. And thus there is hope that other teachers would do the same. Kurt has seen some of this hope in fruition. He described how some of his students who learned through an STSE approach in the 1980s and 90s speak for social issues and citizenship in science curriculum. He shared:

Now what eventually happened, which is, I find quite interesting and quite rewarding, is that because we were doing this over a long period of time, eventually some of our students became science teachers ... a number of them became quite active as science teachers and were on department of education curriculum committees and... as they started pushing for that, some of the curriculum slowly changed. Some of the exams.... I think we need to explicitly address that. We can't ignore it...And I'm firmly convinced that that can be done at the same time as accomplishing all the little bits and pieces and facts and information that you do in math or you do in science. (Kurt, 1st interview)

The authors' hopes for embedding peace and sustainability were placed in the local action of teachers, as noted in the above subsection. However, this hope was predicated on the teachers having had learning opportunities that allowed them to recognize science in society. John and Kurt both described how their work at introducing socio-environmental issues into their teaching and writing arose from their reading and interactions with educators who promoted this. And, as noted above, Kurt described how some younger teachers were building from their experiences of school science that had strong components of values and issues. He has hope that these teachers will include socio-environmental issues in their science teaching. 


\section{Discussion}

\section{Hope Without Agency}

Science textbooks, which are often perceived as curriculum, present the key determinant of the content and context of knowledge, skills, and even interpretations of important and sensitive issues in society. Social issues and values in science teaching such as peace, sustainability, and responsibilities for human agency amidst these concerns present ongoing challenges under the current climate of standardization in competency-based educational systems. Under this climate, textbook authors experience textbook writing as a complex decision-making process addressing the needs of various stakeholders including curriculum development committees, government, publishers, teachers, and students. For the authors in this study, the complexity of this decision-making challenged the authors' beliefs, efforts, and hopes for developing awareness, knowledge, and stewardship in science through textbook content. These challenges came throughout the process from conceptualizing, to writing, to being edited, through to authorization. Value-laden contents were cautioned and resisted by business sectors, the government, and also teachers who viewed science teaching as a neutral, value-free action. The challenges of bringing social contexts of science into textbooks did not seem alleviated over time in the narratives given by the individual authors, nor in the composition of their narratives which collectively described decades of education. Kurt and John shared freedom and agency in acting on their hopes for writing peace and sustainability in textbooks, but these were not possible with commercial publishing companies and current authorization processes used by the government. This challenge was shared by Lucas and Mark in the 2000s with well-known commercial publishing companies. Yet, the most challenging part of textbook writing for sustainability, peace, and social justice was not so much with the publishing companies but with the authority of review and authorization committees of various stakeholders such as the ministry of education and local business sectors. There were diverse arguments of scientific literacy clearly existing in textbook writing processes. Some members of authorization committees mainly focused on science knowledge and skills for everyday problems and economic development and further students' competitiveness to equip and sustain future scientists and engineers for society.

Through these stories, textbook authors' hopes for embedding peace and sustainability were located beyond their agency. They commented that they did not foresee this process changing significantly in future textbook writing. They shared impossibilities of writing for peace and sustainability in textbooks under the current publishing system. Their pessimism is borne out by years of scholarship from Kuhn (1970) to Hyland (2000). In the challenges identified by the authors, relationships of power were clearly present, especially in the resistance to their innovative work. Their agency was negotiated and suppressed; yet, with the constraints through the power of authorization, they hoped to have some changes in curriculum documents, which could support and legitimate their actions of illuminating socio-environmental sustainability issues in science textbooks. With science teachers' resistance, they echoed, unless peace and sustainability were clearly stated in the curriculum, those issues would not be discussed in science classrooms. We saw their hopes in this context as transcendent hope which remains external and out of reach in their actions because the hope depended on the views of stakeholders who tended to hold utilitarian and economic arguments of scientific literacy with standardized concept-based science curriculum. This transcendent hope positions textbook authors beyond their agency as any changes in the government-based authorization process and in the provincial curriculum are political and are not easily reached by individuals. In this hope, there is a lack of agentic thinking which requires one's successful determination to achieve goals (Snyder et al., 2001), thus, passivity and disengagement. 


\section{Hopes in Classroom Actions}

Despite all the challenges shared by the authors in this study, we also saw their hope in the local inter/ actions of teachers. This hope is immanent and promising because it is within the reach of classroom actors. As all the authors were school teachers during the textbook writing process, their narratives were not separate from their interactions with other teachers who were implementing the textbooks. They felt assured that it was the teachers' decisions and action that would bring out values and issues in science classrooms, and the science textbooks could be a tool for them to communicate and interact with the teachers. The personal responsibility taken by teachers could impact the children in front of them. Collectively this praxis could make possible a change in society's view of science. The classroom as a site of immanent action could allow for the possibility of envisioning a pathway through science teaching for a peaceful and sustainable world. The textbook authors stated the teachers' actions that brought hope for peace and sustainability through and beyond their textbooks. Mark indicated promoting peace and sustainability was more than resource development. There needed teachers' action in classrooms to develop peaceful and sustainable relationships among science, human society, and the environment. A hope was emerging from and through teachers' perceptions and actions with the textbooks in classrooms. The hope was immanent, feasible, and directly related to changes in teaching and learning. When the authors put their hope in transcendent powers such as authorization processes or curriculum change, they shared pessimistic thoughts that there would not be much progress in bringing social issues and values in science textbooks and science teaching. Yet, their experiences with science teachers who were implementing science textbooks assured them that they were encouraged and hopeful for future science teaching for a peaceful and sustainable society.

As a possible action for the future direction of textbooks, the textbook authors positioned their hope in exploring alternative teaching resources. With the local agency of teachers, the accessibility and availability of web resources are opening another possibility of immanent hope for peace and sustainability in science education. Some issues in society and the environment are local, current, context-specific, and rapidly changing. Thus, it is almost impossible to update science textbooks to keep them current with the timely issues. For example, the new pandemic situation of COVID-19 is happening right now and scientific knowledge, skills, and human experiences around the pandemic won't be updated in science textbooks for some time. Accessing web resources is one of the most affordable ways to understand knowledge of specific issues that are new, current, and locally embedded (Kim \& Wong, 2020), in other words, immanent issues. The immanent hope to develop values and social justice in science may not exist in textbook content innovations but in teachers' ways of thinking and action to develop and use alternative texts such as web resources focusing on socio-environmental issues. With this hope, teachers' responsibility, knowledge, and skills to evaluate the reliability and trustworthiness of web information also become critical in this possibility (Cho \& Afflerbach, 2015). We suggest that these critical thinking skills point to the need to support developing and experienced teachers as professionals, who make decisions about pedagogy and who are equipped to critically examine available resources. With digital tools and accessibilities, teachers also write and share quality resources to teach what they believe are important for students' scientific literacy. In this process, teachers' actions as resource writers and users are the possibilities of immanent hope.

There are challenges in the immanent hope with teachers' actions on any types of teaching resources including textbooks and web resources. As the textbook authors described teachers' actions with resistance towards talking about values in science classrooms, teachers' perceptions on science and science teaching are critical questions in the development of the immanent hope. The previous research explains that teachers' perceptions on what counts as science are complexly related to their decision-making and actions in classrooms, especially in terms of practicing social and value-related aspects of science (e.g. Abd-El-Khalick, 2013; Cofré et al., 2019; Kelly \& Erduran, 2019; Pedretti 
et al., 2008; Pedretti \& Bellomo, 2013). When teachers understand and appreciate the interconnection between science and values, they take efforts to introduce values in their science classrooms (Sadler et al., 2006). Thus, developing the immanent hope in textbook organization and implementation requires collective efforts to examine one's own perceptions of science and values and to critically analyse the content of science textbooks for classroom teaching. This is also critical in the current classrooms as teachers are also writers, organizers, and/or users of web information for science teaching, thus, learning how to create and analyse texts critically for embedding values and issues in science is critical.

\section{Closing Remarks and Limitations}

Our distinction between transcendent hope and immanent hope arose out of our attention to the authors' descriptions of hope and action. Transcendent hope in curriculum change and authorization process was passive, pessimistic, and hard to reach. There were possibilities and hopes for teaching science with values and issues in classrooms. This immanent hope further highlighted the agency of teachers who take actions. Between going back and forth the boundaries of possibilities and challenges, we learned how complex it would be to shift the discourse of scientific literacy in textbooks today. There were hopes and fears that coexisted. In the beginning of the study, we were hopeful to learn feasible ways to bring SDGs in science classrooms through the textbook authors' experiences and stories; yet, their stories reminded us of textbook writing as a political process and challenged us to question if we ourselves held a transcendent hope in terms of textbook changes. Yet, their stories also reassured us the hope of human agency that interprets, implements, and analyses the topics of the textbook in a creative, critical, and responsible manner.

There are limitations in this study. The textbook authors were also school teachers; thus, their stories were intertwined with their interactions with other teachers and students. Further, this study did not include stories from other sectors such as stakeholders who were part of the writing and decision-making process. Inviting their stories in future studies will help us understand the complexity of textbook writing, the discourse of scientific literacy, and curriculum connections. We also acknowledge that the researchers' hopes for SDGs in science education were interwoven throughout the study. Our background knowledge, experiences, and hopes were the influential aspects on how to develop interview questions, interpret the authors' narratives, and discuss their hopes with our understanding of hope. The reflexivity could be the limitation of the study; yet, rather than emphasizing the complete bracketing of textbook authors' stories from our backgrounds, we chose to explain explicitly how the research was initiated based on our previous discussion on embedding SDGs in school textbooks as a practice of reflexivity. In this way, we believed that we as educators, researchers, and citizens could honour and share the textbook authors' stories with others in a meaningful and collective way.

\section{Appendix. Interview questions}

Background information:

1. When did you write a science/math textbook and for what grade?

2. How many years/books did you write?

3. What made you decide to write textbooks? Why/how did you become interested in textbook writing?

4. Have you had any K-12 teaching experiences? And what is your current relation to education? 
Writing experiences:

1. What part did you like about textbook writing? Can you give us some examples or point out some samples in your textbooks?

2. What challenges did you encounter during textbook writing?

3. How did you cope with the challenges?

4. Did you have any priorities in your textbook writing? For example, curriculum relation, fun and interesting activities, depth and accuracy of contents, students' interests and everyday connection, etc.

5. Were there any requirements from the publishers?

6. Were there any contradictions between what you were asked to do and what you wanted to write on the textbooks?

7. Is there anything that you would write differently for your next textbook writing?

Peace and sustainability:

1. Setting aside the idea of talking about textbooks. Can you describe for me your hopes for society? Think about the children in schools. What are your hopes for them?

2. What about fears? What do you fear the children will face in their future?

3. Do you have any hopes and fears for society? What would be imperatives for teaching and schooling for teaching for peace and sustainability?

4. Do you think embedding peace and sustainability should be prioritized in new textbook writing?

5. Do you think it is important and possible to develop awareness and knowledge of peace and sustainability through science/math teaching?

6. Do you think it would be possible to embed those issues in textbooks? How?

7. Have you ever tried to embed them in your textbook writing? How was the experience?

8. What were the challenges that you experienced?

9. If not, what challenges do you think you might encounter if you were trying to embed those issues in your writing?

10. If you write a new textbook, what strategies would you have to embed peace and sustainability issues in your textbooks?

11. Would you suggest textbook writers attempt to embed those? If so, can you suggest some ideas on embedding those issues in textbooks as a textbook writer?

12. If not, why would you not suggest it?

\section{References}

Abd-El-Khalick, F. (2013). Teaching with and about nature of science, and science teacher knowledge domains. Science \& Education, 22(9), 2087-2107.

Abd-El-Khalick, F., Waters, M., \& Le, A.-P. (2008). Representations of nature of science in high school chemistry textbooks over the past four decades. Journal of Research in Science Teaching, 45(7), 835-855.

Adelabu, D. H. (2008). Future time perspective, hope, and ethnic identity among African American adolescents. Urban Education, 43(3), 347-360.

Altbach, P. G. (1991). The unchanging variable: Textbooks in comparative perspective. In P. G.

Barad, K. (2003). Posthumanist performativity: Toward an understanding of how matter comes to matter. Signs: Journal of Women in Culture and Society, 28(3), 801-831.

Barad, K. (2007). Meeting the universe halfway: Quantum physics and the entanglement of matter and meaning. Durham, NC: Duke University Press.

Berry, T. (2004). Ethics and ecology. In M. Seymour (Ed.), Educating for humanity: Rethinking the purposes of education (pp. 145-154). Boulder, CO: Paradigm. 
Blachowicz, J. (2009). How science textbooks treat scientific method: A philosopher's perspective. The British Journal for the Philosophy of Science, 60(2), 303-344.

Calado, F. M., Scharfenberg, F-J., \& Bogner, F. X. (2015). To what extent do biology textbooks contribute to scientific literacy? Criteria for analysing science-technology-society-environment issues. Education Sciences, 5(4), 255-280.

Cannady, M. A., Greenwald, E., \& Harris, K. N. (2014). Problematizing the STEM pipeline metaphor: Is the STEM pipeline metaphor serving our students and the STEM workforce? Science Education, 98(3), 443-460.

Chambliss, M. J., \& Calfee, R. C. (1998). Textbook for learning: Nurturing children's minds. Malden, MA: Blackwell Publishers.

Chang, E. C., \& Banks, K. H. (2007). The color and texture of hope: Some preliminary findings and implications for hope theory and counselling among diverse racial/ethnic groups. Cultural Diversity and Ethnic Minority Psychology, 13(2), 94-103.

Chiappetta, E. L., Ganesh, T. G., Lee, Y. H., \& Philips, M. C. (2006, April). Examination of science text- book analysis research conducted on textbooks published over the past 100 years in the United States. Paper presented at the meeting of the National Association for Research in Science Teaching, San Francisco, CA.

Cho, B.-Y., \& Afflerbach, P. (2015). Reading on the Internet: Realizing and constructing potential texts. Journal of Adolescent \& Adult Literacy, 58(6), 504-517.

Clandinin, D. J., \& Connelly, F. M. (2000). Narrative inquiry: Experience in story in qualitative research. San Francisco: Jossey-Bass.

Cofré, H., Núñez, P., Santibáñez, D., Pavez, J., Valencia, M., Vergara, C. (2019). A critical review of students' and teachers' understandings of nature of science. Science \& Education, 28(3-5), 205-248.

Davies, B. \& Harré, R. (1990). Positioning: The discursive production of selves. Journal for the Theory of Social Behaviour, 20(1), 43-63.

Davis, J., \& Fonger, N. (2015). An analysis framework for categorizing the use of CAS symbolic manipulation in textbooks. Educational Studies in Mathematics, 88(2), 239-258.

DeBoer, G. E. (1991). A history of ideas in science education: Implications for practice. New York: Teachers College Press.

DiGiuseppe, M. (2014). Representing nature of science in a science textbook: Exploring author-editor-publisher interactions. International Journal of Science Education, 36(7), 1061-1082.

Douglas, K. A., \& Strobel, J. (2015). Hopes and goals survey for use in STEM elementary education. International Journal of Technology and Design Education, 25(2), 245-259.

Freire, P. (1994). Pedagogy of hope: Reliving Pedagogy of the Oppressed. New York, NY: Continuum Publishing Company.

Goldstein, S. (2016). Reflexivity in narrative research: accessing meaning through the participant-researcher relationship. Qualitative Psychology, 4(2), 149-164.

Goodson, I., \& Gill, S. (2011). Narrative pedagogy: Life history and learning. Pieterlen, Switzerland: Peter Lang.

Halpin, D. (2003). Hope and education: The role of the utopian imagination. London, UK: Routledge.

Harré, R., \& van Langenhove, L. (1999). The dynamics of social episodes. In R. Harré \& L. van Langenhove (Eds.), Positioning theory (pp. 1-13). Malden, MA: Blackwell.

Hughes, S. (2011). Justice for all or justice for just us? Toward a critical race pedagogy of hope through brown in urban education. Urban Education, 46(1), 99-110.

Hyland, K. (2000). Disciplinary discourses: Social interactions in academic writing. London, UK: Pearson Education Limited.

Idan, O., \& Margalit, M. (2013). Hope theory in Education systems. In G. M. Katsaros (Ed.), Psychology of hope (pp. 139-160). New York: Nova Publishers.

Kelly, G. J. (2007). Discourse in science classrooms. In S. K. Abell \& N. G. Lederman (Eds.), Handbook of research on science education (pp. 443-470). Mahwah, NJ: Erlbaum.

Kelly, R., \& Erduran, S. (2019). Understanding aims and values of science: Developments in the junior cycle specifications on nature of science and pre-service science teachers' view in Ireland. Irish Educational Studies, 38(1), 43-70.

Khine, M. (2013). Analysis of science textbooks for instructional effectiveness. In M. Khine (Ed.), Critical analysis of science textbooks (pp. 303-310). Dordrecht, The Netherlands: Springer.

Kim, M., \& Wong, S. (2020). Trustworthiness challenge in children's environmental problem solving in the digital era. In T. W., Teo, A-L., Tan, \& Y.S. Ong (Eds.), Science education in the 21st century: Re-searching issues that matters from different lenses (pp. 137-152). Singapore: Springer Nature Singapore Pte. Ltd.

King, C. (2013). A review of the earth science content of science textbooks in England and Wales. In M. Khine (Ed.), Critical analysis of science textbooks (pp. 123-160). Dordrecht, The Netherlands: Springer.

Kuhn, T. (1970). The structure of scientific revolutions (2nd ed.). Chicago, IL: The University of Chicago Press.

Lee, J., \& Catling, S. (2017). What do geography textbook authors in England consider when they design content and select case studies? International Research in Geographical and Environmental Education, 26(4), 342-356.

Lichterman, P. (2017). Interpretive reflexivity in ethnography. Ethnography, 18(1), 35-45.

Loomis, S., Rodriguez, J., \& Tillman, R. (2008). Developing into similarity: global teacher education in the twenty-first century. European Journal of Teacher Education, 31(3), 233-245.

Ludema, J.D. (2000). From deficit discourse to vocabularies of hope: The power of appreciation. In D. Cooperrider, P.F. Sorenson, D. Whitney, \& T.F. Yaeger (Eds.), Appreciative enquiry: Rethinking human organization towards a positive theory of change (pp. 239-261). Champagne, IL: Stipes Publishing. 
Malekan, M. (2008). Battlegrounds for control: A critical review of the Ontario Grade 1-8 science curriculum. Canadian Journal of Science, Mathematics and Technology Education, 8(2), 169-187.

McDonald, C. V., \& Abd-El-Khalick, F. (2017). Preface. In C. V. McDonald \& F. Abd-El-Khalick (Eds.). Representations of nature of science in school science textbooks: A global perspective (pp. ix-xi). New York, NY: Routledge.

McTigue, E., \& Slough, S. (2010). Student-accessible science texts: Elements of design. Reading Psychology, 31(3), $213-227$.

Miller, P. (2009). Stories have histories: Reflections on the personal in personal storytelling. Taiwan Journal of Anthropology, 7(1), 67-84.

Muspratt, S., \& Freebody, P. (2013). Understanding the disciplines of science: Analysing the language of science textbooks. In M. Khine (Ed.), Critical analysis of science textbooks (pp. 33-60). Dordrecht, The Netherlands: Springer.

Niaz, M., \& Maza, A. (2011). Nature of science in general chemistry textbooks. Dordrecht, The Netherlands: Springer.

Nishino, R. (2008). The political economy of the textbook in Japan, with particular focus on middle-school history textbooks, ca. 1945-1995. Internationale Schulbuchforschung, 30(1), 487-514.

Osborne, J. (2010). Science for citizenship. In J. Osborne, \& J. Dillon (Eds.), Good practice in science teaching: What research has to say (2nd ed.) (pp. 46-67). London, UK: McGraw-Hill.

Otto, M. (2018). Textbook authors, authorship, and author function. In E. Fuchs, \& A. Bock (Eds.), The Palgrave handbook of textbook studies (pp. 95-102). New York: Palgrave Macmillan.

Palaiologou, I., \& Male, T. (2016). Critical hope or principled infidelity? How an urban secondary school in an area of sustained poverty in England continues to improve. The Urban Review, 48(4), 560-578.

Pedretti, E., \& Bellomo, K. (2013). A time for change: Advocating for STSE education through professional learning communities. Canadian Journal of Science, Mathematics and Technology Education, 13(4), 415-437.

Pedretti, E., Bencze, L., Hewitt, J., Romkey, L., \& Jivraj, A. (2008). Promoting issue-based STSE perspectives in science teacher education: Problems of identity and ideology. Science \& Education, 17(8-9), 941-960.

Penney, K., Norris, S., Phillips, L., \& Clark, G. (2003). The anatomy of junior high school science textbooks: An analysis of textual characteristics and a comparison to media reports of science. Canadian Journal of Science, Mathematics and Technology Education, 3(4), 415-436.

Rudolph, J. L. (2002). Scientists in the classroom: The cold war reconstruction of American science education. New York: Palgrave.

Rudolph, J. L. (2003). Portraying epistemology: School science in historical context. Science Education, 87(1), 64-79.

Sadler, T., Amirshokoohi, A., Kazempour, M., \& Allspaw, K. (2006). Socioscience and ethics in science classrooms: Teacher perspectives and strategies. Journal of Research in Science Teaching, 43(4), 353-376.

Salmani, B., Hakimzadeh, R., Asgari, M., \& Khaleghinezhad, S. A. (2015). Environmental education in Iranian school curriculum: A content analyses of social studies and science textbooks. International Journal of Environmental Research, 9(1), 151-156.

Sharma, A. \& Buxton, C. A. (2015). Human-nature relationships in school science: A critical discourse analysis of a middle-grade science textbook. Science Education, 99(2), 260-281.

Snyder, C. R. (2002). Hope theory: Rainbows in the mind. Psychological Inquiry, 13, 249-275.

Snyder, C. R., Rand, K. L., \& Sigmon, D. R. (2002). Hope theory: A member of the positive psychology family. In C. R. Snyder \& S. Lopez (Eds.), Handbook of positive psychology (pp. 257-276). New York: Oxford University Press.

Snyder, C. R., Sympson, S. C., Michael, S. T., \& Cheavens, J. (2001). The optimism and hope constructs: Variants on a positive expectancy theme. In E. C. Chang (Ed.), Optimism and pessimism: Implications for theory, research, and practice (pp. 101-125). Washington, DC: American Psychological Association.

Sunal, C. S., \& Sunal, D. W. (2008). Reports from the field: Elementary teacher candidates describe the teaching of social studies. International Journal of Social Education, 22(2), 29-48.

Talanquer, V. (2007). Explanations and teleology in chemistry education. International Journal of Science Education, 29(7), 853-870.

Tiger, L. (1999). Hope springs eternal. Social Research, 66(2), 611-23.

UNESCO and Mahatma Gandhi Institute of Education for Peace and Sustainable Development (UNESCO MGIEP). (2017). Textbooks for sustainable development: A guide to embedding. Retrieved from https://www.medbox.org/health-policy-theglobal-health-landscape/textbooks-for-sustainable-development-a-guide-to-embedding/toolboxes/preview?q=

United Nations. (2015). Transforming our world: The 2030 agenda for sustainable development. Retrieved from https:// sustainabledevelopment.un.org/content/documents/21252030\%20Agenda\%20for\%20Sustainable\%20Development $\%$ 20web.pdf

Wilson, S. (2001). What is an indigenous research methodology? Canadian Journal of Native Education, 25(2), $175-179$.

Zhao, Y., \& Hoge, J. (2005). What elementary students and teachers say about social studies. The Social Studies, 96(5), 216-221.

Publisher's Note Springer Nature remains neutral with regard to jurisdictional claims in published maps and institutional affiliations. 